\title{
Diagnosing, special education, and 'learnification' in Danish schools
}

\author{
Bjørn Hamre \\ Danish School of Education \\ Aarhus University \\ Email: bjha@edu.au.dk
}

\begin{abstract}
This article focuses on a discussion of diagnosing, special education, and 'learnification' in a Danish school context in which the increasing use of diagnosis is analysed as resulting from the ideas of normality that are associated with the construction of the pupil as a learner. I argue that diagnosis in schools can be seen as the shadow side of the articulation and management of learning through schools' requirements for pupils. This article is based on my analysis of files produced by educational psychologists. Learning and diagnosis, I argue, constitute two different, but parallel, ways of looking at being a pupil in school, each of which represents conceptions of deviance and normality. The article's methodological point of departure draws on a Foucauldian-influenced analysis of diagnosing and learning in education.
\end{abstract}

Keywords: Learning, diagnosing, special needs education, learnification, psychopathology, Denmark

\section{Introduction}

According to Søren Langager (2014), 'the number of children and teenagers who are given a clinical diagnosis is increasing so dramatically that the development has been called a tsunami of diagnoses because it has taken place over so few years in Denmark' (p. 284). This article focuses on a discussion of these issues in a Danish school context in which the increasing use of diagnoses is analysed as resulting from the ideas of normality that are associated with being a learner in school, similar to what Gert Biesta (2006) has termed 'learnification'. I argue that diagnosing in schools can be seen as the shadow side of the way in which learning is articulated and managed through schools' requirements for pupils, and the ways in which categorizations of problems are constructed in schools today. Categorizations of problems take place whenever a particular kind of behaviour, defined as problematic at the school level, leads to different professional actions within schooling and especially within special-needs education. This article is based on my research into files produced by educational psychologists during the period from 2000 to 2010. 
Langager (2011) touches on the dilemma in Danish national school policy: on the one hand, ideals of inclusive schooling have led to a reduction in the number of pupils referred to special support outside the ordinary school environment, and, on the other hand, an increasing number of children are given a clinical diagnosis, most typically Attention Deficit Hyperactivity Disorder (ADHD). Pupils who used to be regarded as having behavioural or psycho-social problems are increasingly categorized with neurological dysfunction in child psychiatry. These issues are not isolated to the Danish context, and can be analysed as an international tendency. Harwood and Allan (2014) refer to the trend towards psychopathology at school, which points to the increasing tendency for children and young people who exhibit risk behaviour in school to be regarded as having psychiatric difficulties that require medication. The ever-increasing use of the diagnosis of ADHD is an example of the interpretation of children's problems in psychiatric terms by school professionals. There is also a trend for increasingly younger children to be diagnosed in terms that were previously reserved for adults. The analysis of this trend also includes Valerie Harwood's book: Diagnosing 'Disorderly' Children: A Critique of Behaviour Disorder Discourses (2006), in which she applies Foucault's concepts to produce a critique of the tendency to diagnose children as 'disorderly', specifically with the term 'conduct disorder'. In her critique she touches on issues like the power of the expert regimes, psychiatry as a powerful discourse, and the increasing medicalization of children and young people. This critical perspective of medicalization in schools and special-needs education is also followed in the medicalization in schools (Harwood \& McMahon, 2014).

The majority of Foucauldian-influenced research in disability studies and special education has followed a tradition of taking a critical approach to diagnosis as an expression of the individualization of human deviation (Corker \& Shakespeare, 2006; Tremain, 2005; Goodley \& Rapley, 2002). However, diagnosing may be part of a broader cultural tendency rather than just a categorization of deviancy. In his book The Politics of Life Itself: Biomedicine, Power and Subjectivity in the Twenty-First Century (2007), Nikolas Rose, for example, described diagnosis as a cultural tendency to perceive life as biological citizenship, where individuals are subjectivized and expected to take increasing responsibility for their own health and diseases. In the light of biological citizenship, diagnosis can be seen as something that not only restricts, but also provides access to options for treatment and financial privileges (see also Rabinow \& Rose, 2003; Hughes, 2009).

This article argues that diagnosing may be understood and interpreted in relation to the way learning has been positioned in contemporary schooling today. Diagnosing as well as learning thus constitutes two equally important conceptions of how normality and deviancy are constructed. Rather than following the insights of the studies mentioned above, I argue that the frequency with which pupils in schools are diagnosed may be related to the way 'learning' and 'the learner' have been positioned as an ideal in schools. Drawing on an empirical study of documents in schools, I show that 'the diagnosed pupil' seems to be constructed as someone who has difficulties with everything the 'learner' is expected to be able to do (Hamre, 2012). Files produced by educational psychologists include descriptions of problems showing, for example, that diagnosed pupils have difficulties with being the curious, changeoriented, positive, and social individuals that the standards of education stipulate they ought to be. In this article I argue that learning is primarily relevant for understanding how normality is constructed, and that diagnosing is important in the construction of deviance. Through an analysis of my own empirical findings, I shall elaborate on the construction of diagnosis and learning as two 
different but entangled phenomena that relate to the way in which pupils are interpreted as successful or not in current schooling.

\section{Subjectification and problematization}

The analysis of the empirical findings regarding 'diagnosing' and 'learning' mainly draw on Foucault's concepts of subjectification and problematization. Theoretically, I consider diagnosis to be a technology that situates individuals in a particular form of identity. Here I am informed by the three types of subjectivity outlined by Foucault (Foucault, 1982), namely, scientific classification (such as psychiatry), dividing practices (e.g., exclusion to special education), and subjectification (e.g., the ways in which diagnosed pupils define themselves as different). Diagnosis is thus deemed to be a technology that creates the pupil in a specific way in the school. Drawing on Foucault's theories on subjectification, I apply the term 'subject' as an analytical description of the individual in the article. Using technology as a term, I thus drawn on Foucault's theories on how the individual becomes a subject, as sketched out in the three types above. I have chosen to analyse learning by using Foucault's methodological concept of problematization (Foucault, 1985, 1997, 1998). This term has gone relatively unnoticed, and, according to Paul Rabinow (2003), it is only in Discipline and Punish (Foucault, 1979) where it is used in its explicit meaning. In this article, I argue that learning is an expression of such a typical current problematization of phenomena in schooling which simultaneously positions some pupils as non-learners, or perhaps as diagnosed individuals. Diagnosing and learning are the key empirical findings in my quantitative approach to the data. I shall now turn to this empirical study.

\section{Construction of data}

As mentioned above, the empirical data in the study stems from 44 files of pupils examined by educational psychologists and referred to special-needs education in Copenhagen Municipality. These files stem from the department responsible for schooling and the referral of pupils to special-needs education in Copenhagen in the period from 2000 to 2010. The files include various documents, such as evaluations of pupils, psychological, and psychiatric examinations, and objectives for how the pupil is supposed to develop in special-education contexts. In line with Foucault, a file is seen as an expression of a technology and a dividing practice that subjectivizes the pupils. The files are thus applied to demonstrate how modern schooling constructs differences between pupils who are included and those who are excluded.

\section{Diagnosis - analysis of data}

Drawing on the files, I argue that diagnosing in schooling often appears as something negative with regard to the image of a pupil (Hamre, 2012). The person who is diagnosed stands out as an individual who is not able to meet the expectations of being a learning subject. The analysed files make it clear that pupils are expected to fulfil requirements for emotional self-awareness and flexibility if they wish to be regarded as normal in schooling. From this perspective, the diagnosed pupils in the files' descriptions of problems have failed, since they have not managed to act as successful learners who live up to the expectations of the schools. Many of these pupils are referred to specialeducation schools. Special-needs education can be regarded in this perspective as a compensatory response whereby the pupils, through different educational manuals, methods, and pupil-plans are positioned as individuals who need 
guidance in order to appear as more successful pupils. The diagnosis appears in these documents as self-technologies, with pupils being expected to use their knowledge of their own diagnostic symptoms and behaviour to work with themselves in order to fulfil their potential as subjects of schooling. This can be observed, for example, in the child psychiatric files produced by the educational psychologists. These files describe the pupils not only in biographical terms with reference to their family history, using an examining process that results in a diagnosis, but also in the form of educational guidelines for the pupils diagnosed. As a knowledge regime, psychiatry exerts a hegemony that pervades the special educational approach to problems. In this case the diagnosis appears as a subjectification; it works both as a dividing practice and as a self-technology in the sense that the pupil works with her identity as a diagnosed pupil. Drawing on the above-mentioned child psychiatry files, I have found that this subjectification appears in four different ways (Hamre, 2012, p. 202). In addition to the information required for medical treatment, recommendations are thus made at four levels: 1) referral of the child to an institution of some kind, 2) the advice of the professionals who work with the child, 3) the guidance of the child's parents, and 4) the therapy and educational initiatives directed at the child. In the medical records there is a tendency for diagnostic technology to position the pupil as working with their own diagnosis. The diagnosis in the files is associated with a number of technologies that involve a certain subjectification of the pupil. Apart from the diagnosis itself and the related medication, these technologies include educational training and guidance plans for the individual pupil, classes involving teaching in disability awareness as a personal issue, and 'social-classes' in which the diagnosed pupils are taught about social behaviour. These activities position the pupils as individuals who are expected to reflect on themselves as diagnostic subjects, involving special-education awareness. In an educational context, diagnosing might be a way to categorize pupils who are perceived as troubled or troublesome in modern schooling. Informed by Rose (2007), the diagnosed pupils in child psychiatric examinations and in special-education schools are manoeuvred into a biological view of themselves and their existence. This biological subjectification appears in the analysed files and documents from the special-education schools as an imperative, 'Know yourself and your diagnosis', encouraging the pupils to work with themselves as diagnostic subjects. For instance, this happens through the use of educational material such as 'Asperger's syndrome - what's in it for me?', in which the pupil is positioned as someone who needs to reflect upon himself or herself as a diagnostic subject. The medication itself also has a role to play when it appears in the educational settings with regard to producing pupils as biological subjects. For example, one of the child psychiatric files mentions Ritalin's beneficial effect on a pupil's attendance at school, including its influence on the pupil's emotional insight and development in relation to concentration, changes in the school environment, the ability to defer needs, and so on. It describes how the medication has had the positive effect that a pupil is now able to speak out - without becoming aggressive and, not least, exhibiting an emerging understanding of disability in relation to his or her own and others' problems. Among other positive effects attributed to the medication is 'much more calm and coherence'. The medication of pupils together with organized work with their self-awareness and emotional habitus operate as two sides of the same coin, subjectivizing them as less problematic in relation to the school's expectations of normality. The diagnosed pupils in the educational setting are positioned as emotional and biological individuals who are engaged in an effort to understand themselves with respect to their disability. The pupil-plans in special-needs education reflect ambivalence. On the one hand, they position the pupil as lacking understanding, which highlights pupils' inability to meet the school's requirement to practise self-knowledge, and generally manifest themselves as successful school 
subjects. On the other hand, the pupil-plans at the same time emphasize the diagnosed pupils' potentiality, placing them in a learning position in which they are expected to adapt to the 'know-yourself' imperative mentioned above.

\section{Diagnosing - analytical perspectives}

Diagnosing in schooling plays the role of a certain kind of subjectivity, positioning the pupils as unsuccessful learners. According to Langager's (2008; Langager \& Sand Jørgensen, 2011) research, a new kind of positivity has arisen through the development of brain science, draped in diagnosis, which results in a waiver of individual responsibility for the diagnosed individuals and their parents. The result is a new landmark in the understanding of issues among children because diagnoses are then surrounded with a form of exclusivity, triggering resources for a child. Yet children with social or psycho-social problems, or both, who are 'non-diagnosed' but still 'different' are subjectivized as clients and are met with requirements for self-normalization. However, it is not easy to define the two different groups. The picture is complicated by the fact that a diagnosis of ADHD can occur in combination with several other diagnoses related to anxiety, depression, behavioural disorders, and so forth. The trend is towards children being diagnosed with 'complex problems'. Special-education issues that were formerly described as behavioural problems and learning disabilities are now classified as 'supplementary diagnoses', and thus social and emotional problems are covered by a diagnosis (Langager \& Sand Jørgensen, 2011, p. 24). According to the Danish professor of psychology, Svend Brinkmann, this has resulted in a social and cultural tendency to treat diagnosis as a way of relating to existential problems (Brinkmann, 2010, 2011; Rose, 2007, 2010). Phenomena that were previously seen as part of human life have become pathologized on the basis of medical and psychiatric terms, with restlessness, for example, becoming ADHD (Brinkman, 2010). According to Rose (2007), the profession's increased use of diagnoses of mental health has increased in importance as an explanatory model for general human and existential problems.

\footnotetext{
... we are witnessing a 'psychiatrization' of the human condition. In shaping our ethical regimes, our relations to ourselves, our judgements of the kinds of persons we want to be, and the lives we want to lead, psychiatry, like the rest of medicine, is fully engaged in making us the kinds of people who we have become. (p. 481)
}

In recent years, psychology has undergone an increasing psychiatrization that threatens its scientific autonomy, and teachers' extensive use of ADHD as a diagnosis is an example of this (Brinkman, 2011). The growing importance of neuropsychology has led to a new form of biological determinism in the observation of people and the ways in which they are positioned in the fields of education, psychology, and psychiatry (Rose, 2007). This implies a shift from perceiving the human being as a psychological self to regarding it as a biological psychiatric self. The Swedish sociologist Thomas Brante $(2011$, p. 73 ) touches on something very similar when he argues that the increase in the number of diagnoses is due to neuropsychiatry having become a truth regime which has achieved hegemony as a scientific discipline, leading to a biologically deterministic view of human differences. The explanation for this hegemony is found not only in pharmaceutical and professional interests, but also in the fact that neuropsychiatry functions as a socially stabilizing factor: 'Neuropsychiatric diagnosis is a relatively inexpensive method for the identification of problems and the maintenance of social order' (Brante, 2011, p. 62). On the basis of the aforementioned sociological and psychological research, we can argue that 
diagnosing is a strong cultural trend that influences the way in which pupils regarded as deviant are subjectivized in modern schooling.

This is also the case in Danish schooling. In the files produced by the educational psychologists (including the child psychiatric files and pupil-plans from the special-needs schools), it can be observed that several diagnoses often occur simultaneously during the diagnostic process. Developmental disturbances, such as those associated with diagnoses, highlight psychological, social, and environmental factors in the child's upbringing. This trend can be seen not only as an expression of the narrowing of the range of normality that meets the school's requirements, but also as an expression of the biologization of psychological and social factors in understanding human problems. These two problems, according to Rose (2007), show a clear correlation:

\begin{abstract}
These disorders on the borders, I think, are experienced and decoded for these purposes by the individuals and their doctors in relation to a cultural norm of the active, responsible, chosen self, which realizes its potential in the world through creating a lifestyle. And they are awarded their kind of available categories, such as depression, panic, social anxiety disorder and ADHD. (p. 480)
\end{abstract}

The diagnosis thus reflects a certain concept of normality. First, we shall consider the disorders on the borders. These disorders are, according to Rose (2007), positioned in a problem-solution complex according to the dictates of psychiatry and biology. This makes perfect sense, in fact, when we consider how child-psychiatric explanations lead to practical instructions for action in schools on the basis of these statements. It can only be interpreted as a clear narrowing of normality when such phenomena as 'loss of confidence' or 'changed family pattern' become supplementary diagnoses, so that phenomena which were previously interpreted in sociological and psychological terms now become clothed in a pathologizing diagnosis. The presence of additional diagnoses such as 'loss of confidence' and 'changed family pattern' in the files might be a manifestation of psychiatry increasingly providing more effective explanations in what has hitherto been regarded as the realm of psychology. This indicates that the school's understanding of problems is shaped by the phenomenon that has been termed 'pathologizing disorder' (Nielsen \& Jørgensen, 2010) and the aforementioned 'psychiatrization of the human condition' (Rose, 2007). When it comes to the sorting of human differences in school, psychiatric diagnoses seem to offer an efficient technology for separating the able from the less able. At special schools it is part of the curriculum that pupils should evaluate themselves and their diagnosis through learning processes. This illustrates what Rose (2007) analyses as the way in which individuals are characterized as biological citizens by having a biological relationship to themselves. In line with the applied data and the subsequent sociological perspectives, diagnosing might be interpreted as a modern way of constructing deviancy, not only in Danish schooling, but also as a general cultural tendency. This leads us to the following question: If diagnosing is a modern way of constructing deviancy in schools, how then is normality constructed?

\title{
The ideal of the learner - analysis of data
}

While diagnosing appears as a self-technology and a current way of constructing deviancy, as seen in the previous section, I argue on the basis of the data that learning and the construction of the 'learner' demonstrate an ideal of normality in current schooling (Hamre, 2012). Learning is, therefore, a 
particular way of problematizing education, and involves a certain subjectification of the pupil that includes an ideal normality as opposed to deviancy. What are the implications of regarding learning as a problematization, and how does it work at the subject level? First, learning is seen as a response to scholastic phenomena in the present. The strong focus on learning can be seen, for example, as a response to the fact that Danish schoolchildren are very poor at reading (cf. PISA studies). This kind of focus on 'learning' is a response to a state that is seen as inadequate. Secondly, learning is seen as something that defines what is perceived as normal or aberrant. The defining of a phenomenon as a problem is tantamount to erecting a boundary between what can be observed, both culturally and institutionally, as being either included or excluded (Fogh Jensen, 2005). In this context, it means that one thing is defined as learning while another thing is defined as non-learning.

The problematization of learning subjectivizes some pupils as learners as social or reflective subjects, and this means that a similar distinction is produced in relation to pupils whose behaviour problem is defined as, for example, psychosocial difficulties, lack of impulse control, or simply that the pupil is a 'problem child', which is still a current designation in the school debate in the media. In line with the data presented in the previous section, diagnosed pupils are positioned as themselves as successful learners. Simply put, it can be said that the ideal of the learner pupil defines the difference between fitness and nonfitness in current schooling. In order to be successful in school, you need to subjectivize yourself as a learning subject. Learning as problematization is visible in three different ways: 1) in the ideal pupil whom today's schools demand, 2) in a special kind of logic that defines how problem understandings are constructed in schools and justifies exclusion, and 3) through a variety of technologies that both reinforce and confirm the construction of the pupil as a learning subject (Hamre, 2012). In these cases, learning is constructed as a matter of potentiality; that is, there is an expectation of perpetual readiness for development. You could call this being in a perpetual state of inconclusiveness or 'maybe-fitness'. Secondly, it is clear that learning is always articulated in a positive way as something unequivocally good, which in principle there can never be too much of. Thirdly, learning is seen as an overall response to the wide range of issues and situations that occur at school. Problems are interpreted as occurring, for example, because the learning method is not taken seriously enough, because the teacher lacks a professional knowledge of learning, or because the professionals have an outdated view of what education is all about (where learning comes in as a solution). The degree of potentiality inherent in learning extends beyond the pedagogical relationship between teacher and pupil, with the responsibility for achieving their potential given to the pupil. Similarly, parents are subjectivized as co-responsible for the realization of their children's potential as learning subjects.

The problematization of learning functions very effectively in addition to this because learning can easily be associated with a wide variety of different phenomena: 1) efficiency, pleasure, and curiosity, 2) happiness, health, and well-being, 3) the phenomenon of 'the learning environment' as a sacred place where something new is likely to occur, and 4) the methods of different learning styles like cooperative learning, where learning takes on the role of redeemer of the unique and personal. Additionally, learning is seen as a response to how the pupil, the teacher, and the organization are expected to orient themselves in a curious and resource-oriented way. At all levels, the message is clear: you have the potential to develop yourself. Any limitations are basically just due to your own lack of ability. For the pupils, it is about subjectivizing themselves as willing individuals who, through a labour of self-esteem, open themselves up for leadership through recognition and therapy-like work with their emotional lives. 
The development of learning strategies positions pupils in their own professional- and personal-development project, which includes looking at themselves to discover their potential.

The problematization of learning thus enables a distinction to be made between what it means to be successful or less successful as a pupil in school. In line with the analytical perspective of this article, the diagnosed pupils have transgressed the standards of what is acceptable to be successful as an individual in current schooling. All pupils are subjected to the standards of being learning subjects, but not everyone manages to be a successful learning subject. Technologies like contracts, action plans, and external targets result in an individualization of schooling in which the individual pupil is evaluated and positioned to take responsibility for the learning process. This involves an expectation that the individual has an active relationship with his or her learning process. With the individualization of the learning project, it has become possible to attribute responsibility for the failure to achieve their full potential to the pupil. Technologies associated with the ideal of learning have thus introduced new dividing practices involving new types of exclusive mechanisms. As a result, learning and its related technologies constitute the most important subjectification in modern schooling. In the section below I shall discuss how these analytical findings might find support in Foucauldian studies on general education.

\section{Learning as an ideal - analytical perspectives}

Gert Biesta's (2006) concept of 'learnification' denotes the increasing tendency for learning to be positioned as the central concept of educational theory in schools and in the training of various professionals. Biesta is critical of the concept of learning, and he analyses it as an expression of how neo-liberalism has affected schools and educational science. This ideal of learning also involves a certain idea of the subject. The deconstruction of learning can also be seen in educational studies as being informed by governmentality studies. In his further development of governmentality, Rose (1998) has discussed the management of the 'subject' in modern society based on the relationship between power and freedom. Managing through freedom is based on a number of managerial technologies (Rose, 1998, p. 67), and this is, therefore, also applicable in the field of schools and education (Fendler, 1998; Popkewitz, 2008). According to the American educational researcher Lynn Fendler (1998), the spread of the concept of learning, as well as allowing pupils to be flexible, is of independent financial value when it comes to generating labour productivity in a globalized economy. The educational system thus reproduces a financial perspective in its requirements for flexibility in training and in the school's educational approach. For the pupils, this requirement for flexibility is synonymous with the ability to adapt, to react to external demands, and to practise self-discipline (Fendler, 1998, p. 20). The education system is expected to produce flexible and adaptable personalities, and the soul is the place where this subjectification of the pupil's personality is expected to occur. This work on the soul performed by each pupil is designed to teach them the importance of being motivated, which includes having the right, positive attitude and a willingness to accept that all features of the personality may be the subject of learning. The construction of the flexible personality in school is related to the fact that school psychology has become a truth regime that creates pupils as psychological subjects (Rose, 1998; Fendler, 1998).

According to Fendler, the school is characterized by a developmentality rationale (Walkerdine, 1998); however, this does not mean a development 
towards freedom. Instead, developmental psychology directs pupils towards self-management in fulfilling the school's requirements and expectations (Fendler, 1998, p. 8). Developmental psychology has become a knowledge regime in which power is exercised through normalization technologies in schools, which is consistent with the state's efforts to format pupils as productive and flexible individuals. Following Fendler's argument, the dominance of the concept of learning in school must, therefore, also be seen from this perspective. The importance of learning must be seen in context, with the notion of the future forming an important part of the modern school. As the Swedish educational researcher Kenneth Hultqvist (2008) claims, 'The concept of learning is both an art and an agenda to the individual to prepare to face a future that is more uncertain than ever' (p. 163). The idea of the future is an effective managerial technology, both when it comes to the repayment of the logics in a globalized economy and for how individuals manage themselves and their time in school. It is here that the idea of the future enters into an alliance with the concept of learning.

The future is not, I would argue, about the time that lies ahead. It is a technology that organises and creates subjects, school children, teachers and parents, and during the course of events links together the two poles of control: control of the individual and control of the population. (Hultqvist, 2008, p. 160)

As a managerial technology, the notion of the future is inscribed in national programmes and standards for the educational planning of each school's curriculum and educational methods, as well as the relationship between the teacher and the learner. Following Hultqvist, I would argue, therefore, that the deployment of the concept of learning in school can be seen as a powerful technology that shapes the pupil as an individual and the population as a whole. We follow the American educational researcher Thomas S. Popkewitz, who argues that lifelong learning has become a cultural ideal. This ideal, according to Popkewitz, should be understood through the concept of cosmopolitanism, a principle that since the Enlightenment has constructed the pupil as a rational, thinking individual. Cosmopolitanism, therefore, determines how, in different historical periods, perceptions of normality construct the pupil as a school subject (Popkewitz, 2008, p. 111). Rationality therefore has three different functions: 1) it produces norms and ideals of how one should be a pupil in school, 2) it organizes differences, because it defines what should be included and excluded, and 3) through the organization of these differences, rationality also produces exclusion. As a managerial principle, cosmopolitanism works in two ways, therefore: on the one hand, it acts as an educational ideal, emancipatory and freeing for the individual, but, on the other hand, it also produces at the same time differences and exclusion in relation to pupils who do not comply with the ideal of the rational individual. The 'learner' is the current ideal of the subject of cosmopolitanism, defining who is to be included and excluded. To sum up: the above-cited studies positions learning as an important problematization in contemporary schooling. In my empirical studies I have demonstrated how the idea of the learner is positioned as the ideal subject in a Danish school context. I argue that the idea of the learner reflects the historical problematization of learning. This can be analysed by taking Foucault's theories of subjectification into account. As we have seen, problematization is a response to a historical phenomenon that is exercising power (Foucault, 1985, 1997, 1998), because it governs what is defined as included and excluded (Howarth, 2005). As a problematization learning also involves solutions to the problem, and it operates at the subject level as well; that is, individuals are subjectivized and subjectivize themselves as learning subjects (Hamre, 2012). Learning thus also works as a subjectification on the three different levels as 
outlined earlier, positioning the learner as an ideal subject. The two phenomena in modern 'learning' and 'diagnosing' in modern schooling may thus represent contemporary constructions of normality and deviancy in modern schooling.

\section{Conclusion}

In light of the analysis of this article, the diagnosed child appears to be a shadowy entity in relation to the ideal of 'the learner', a child who has problems meeting the modern requirements to be curious, motivated, and positive. Proficiency in school is synonymous with a pupil's willingness to work with their potential as an individual learner. The individual in modern schools is thus fixed in a 'maybe-ability', since they will always be subject to the ideal of learning: 'you are always in a process, and it is expected that you will make yourself visible in this process.' Although it sounds ambivalent, this recurring 'maybeability' may have exclusionary functions for some pupils, since they may have difficulties in adapting to ideals of knowing themselves, reflecting upon themselves, manoeuvring in groups, and taking responsibility for their own learning. The inability to fulfil such agendas in contemporary schooling might result in a sort of psychopathologization (Harwood \& Allan, 2014), in which psychological or social problems are constructed and interpreted as psychiatric problems that need treatment and intervention. Accordingly, diagnosing may represent a shadow side of the tendency towards 'learnification' (Biesta, 2006).

In his description in The History of Madness (1973), Foucault described how the modern bourgeois sense was constructed as the ideal of normality by banishing the 'mad' individuals who deviated from it. The ideal of the learner and the diagnosed is a modern example of how the normal constitutes itself by excluding the deviant. The diagnosed pupil is positioned as a subject who has failed to take responsibility for their own learning, thereby representing the ultimate negation of the learning subject. Informed by Foucault, we can interpret diagnostic descriptions not as objective scientific descriptions of pupils' problem, but as constructions that need to be analysed in the current agenda of the school. The school's many diagnoses and the importance of diagnosis have legitimized deviation, which Bernadette Baker (2002) has described as a form of 'newgenics', seen as quality control and the separation of the non-able. Diagnosing represents a new way to separate the competent from the less able in schools, and in this sense is a form of newgenics that deftly ensures the sorting out of those pupils who may not readily be subjectivized as learners, subjects oriented towards a future where knowledge and people need to be transformed in order to fit market conditions.

\section{References}

Biesta, G. (2006). Beyond Learning - Education for a Human Future, London: Paradigm Publisher.

Brante, T. (2011). Striden om den korrekte diagnose og hegemoniet inden for et professionelt område: Videnskabsteoretiske og politiske aspekter. [Dispute about the correct diagnosis and hegemony within a professional field: Theoretical and political aspects] In I. Bryderup (Ed.), Diagnoser $i$ specialpædagogik og socialpædagogik [Diagnoses in Special and Social Education] (pp. 38-77). København: Hans Reitzels Forlag.

Brinkmann, S. (2010). Det diagnosticerede liv - sygdom uden grænser [The Diagnosed Life: Disease without Borders]. Århus: Klim. 
Brinkmann, S. (2011). Om psykiatriseringen af hverdagslivet og psykologien [On the psychiatrization of everyday life and psychology]. Psykologisk set, 28(82), 5-12.

Corker, M. \& Shakespeare, T. (2006). Disability/Postmodernity: Embodying Disability Theory. London and New York: Routledge.

Fendler, L. (in press). Educating flexible souls: The construction of subjectivity through developmentality and interaction. (Originally prepared for the symposium: The Child in a Changing World: Refiguring Early Childhood Education. OMEP Conference, Copenhagen, Denmark, August 13-16, 1998. http://michiganstate.academia.edu/LynnFendler/Papers/322728/Educating Flex ible Souls) In K. Hultqvist \& G. Dahlberg (Eds.), The Child in a Changing World: Refiguring Early Childhood Education. New York: Sage Press.

Fogh Jensen, A. (2005). Mellem ting, Foucaults filosofi [Between things, Foucault's philosophy]. Frederiksberg: Det lille forlag.

Foucault, M. (1979). Discipline \& Punish. The birth of the Prison. New York: Vintage books, Random House.

Foucault, Michel (1973). Galskapens historie [A History of Madness]. Oslo: Gyldendal.

Foucault, M. (1998). History of the Present - On Problematization - (Spring 1998), Berkeley 1983. The text is taken from an edited transcription of tapes of the seminar (without a final revision by Foucault) by Joseph Pearson at Northwestern University. A copy of the publication is housed in the Foucault archive in Paris.

Foucault, M. (1997). Politics, Polemics, and Problematizations. In P. Rabinow (Ed.) The Essential Works of Michel Foucault, 1954-1984, Vol. I, Ethics: subjectivity and truth, (pp. 111-119). London: Allen Lane.

Foucault, M. (1985). The History of Sexuality. Vol. 2, The Use of Pleasure (R. Hurley, Trans.). London: Penguin.

Foucault, M. (1982). The Subject and Power. In H. L. Dreyfuss \& P. Rabinow (Eds.) Beyond Structuralism and Hermeneutics (pp. 208-22 6). Chicago: University of Chicago Press.

Goodley, D. \& Rapley, M. (2002). Changing the Subject: Postmodernity and People with 'Learning Difficulties'. In M. Corker \& T. Shakespeare (Eds.) Disability/Postmodernity: Embodying Disability Theory (pp. 127-142). London: Routledge.

Hamre, B. (2012): Potentialitet og optimering i skolen - Problemforståelser og forskelssætninger af elever - en nutidshistorisk analyse [Potentiality and Optimization in School - Problem Understandings and Unlike Sentences of Pupils: A Present Historical Analysis]. PhD thesis. Institut for Uddannelse og Pædagogik. Aarhus: Aarhus Universitet.

Howarth, D. (2005). Diskurs - en introduktion [Discourse: An introduction]. København: Hans Reitzels Forlag.

Harwood, V. (2006). Diagnosing 'Disorderly' Children: A Critique of Behaviour Disorder Discourses. London: Routledge.

Harwood, V. \& Allan. J. (2014). Psychopathology at School, Theorizing mental disorders in education. New York: Routledge.

Harwood, V., \& McMahon, S. (2014). Medicalization in Schools. In L. Florian (Ed.) The SAGE handbook of special education (pp. 913-930). Los Angeles: Sage.

Hughes, B. (2009). Disability activisms: social model stalwarts and biological citizens. Disability \& Society, 24(6), 677-688. 
Hultqvist, K. (2008). 'Fremtiden' som styringsteknologi og det pædagogiske subjekt som konstruktion ['The future' as control technology and pedagogical subjects as construction]. In Krejsler (Ed.), Pædagogikken og kampen om individet Kritisk pædagogik, ny inderlighed og selvets teknikker [Pedagogy and the Struggle of the Individual: Critical Pedagogy, New Fervour, and Techniques of the Self] (pp. 159-189). København: Hans Reitzels Forlag.

Langager, S. (2014). Children and youth in behavioural and emotional difficulties, skyrocketing diagnosis and inclusion/exclusion processes in school tendencies in Denmark, Emotional and Behavioural Difficulties, 19(3), 284-295.

Langager, S. (2008). Inklusionens paradokser - normalitetsopbrud, normaliseringspolitik og diagnosens privilegier. [Inclusion paradoxes: Normality upheavals, normalization policy and diagnostic privileges]. Dansk Pædagogisk Tidsskrift, 2008(8), $6-13$.

Langager, S. \& Sand Jørgensen, A. (2011). Diagnoser i udvikling - tendenser og konsekvenser i forhold til social- og specialpædagogik [Diagnoses in development: Trends and consequences for social and special education]. In I. Bryderup (Ed.), Diagnoser i specialpædagogik og socialpædagogik. [Diagnoses in Special and Social Education] (pp. 17-37). København: Hans Reitzels Forlag.

Nielsen, Klaus \& Jørgensen Carsten René (2010). Patologisering af uro? [Pathologizing of restlessness?]. In Brinkman (red.), Det diagnosticerede liv - sygdom uden grænser [The diagnosed life: illness without borders] (pp. 179---205). Århus: Klim.

Popkewitz, T.S. (2008). Cosmopolitanism and the Age of School Reform: Science, Education, and Making Society by Making the Child. NY: Routledge.

Rabinow, Paul (2003). Anthropos today - Reflections on Modern Equipment. New Jersey: Princeton University Press.

Rabinow, P. \& Rose, N. (2003). Thoughts on the Concept of Biopower Today. http://www.lse.ac.uk/sociology/pdf/RabinowandRose-BiopowerToday03.pdf.

Rose, N. (1998). Inventing Our Selves: Psychology, Power and Personhood. Cambridge: Cambridge University Press.

Rose, N. (2007): The Politics of Life Itself: Biomedicine, Power, and Subjectivity in the Twenty-First Century. Oxford: Princeton University.

Rose, N. (2006). Disorders Without Borders? The Expanding Scope of Psychiatric Practice, Biosocieties, 1(4), $465-484$.

Walkerdine, V. (1998). Developmental psychology and the child-centred pedagogy: the insertion of Piaget into early education. In J. Henriques, W. Hollway, C. Urwin, C. Venn, \& V. Walkerdine (Eds.) Changing the Subject (pp. 153-202). London: Routledge. 